\title{
Is fasting glucose sufficient to define diabetes? Epidemiological data from 20 European studies
}

\author{
The DECODE-study group on behalf of the European Diabetes Epidemiology Group*
}

Steno Diabetes Centre, Gentofte, Denmark

\section{Abstract}

Aims/hypothesis. The World Health Organisation Consultation recommended new diagnostic criteria for diabetes mellitus including: lowering of the diagnostic fasting plasma glucose to $7.0 \mathrm{mmol} / \mathrm{l}$ and introduction of a new category: impaired fasting glycaemia. The diagnostic 2 -h glucose concentrations for diabetes and for impaired glucose tolerance were unchanged. This study identifies fasting plasma glucose concentrations predicting a diabetic 2-h plasma glucose of $11.1 \mathrm{mmol} / \mathrm{l}$ or more, analyses the sensitivity and specificity of different screening strategies for diabetes and describes the cardiovascular risk profile in people with impaired fasting glycaemia.

Methods. European population based studies $(n=17)$ or large, representative samples of employees $(n=3)$ with both fasting and 2-h post load glucose concentrations following 75 -g oral glucose tolerance tests were included (18 918 men and 10190 women). The Iceland study (8881 men and 9407 women) is presented separately as a $50-\mathrm{g}$ glucose load was used.
Results. The fasting plasma glucose predicting a 2-h plasma glucose of $11.1 \mathrm{mmol} / \mathrm{l}$ or more with optimal sensitivity and specificity was a) $5.8 \mathrm{mmol} / \mathrm{l}$ in women and $6.4 \mathrm{mmol} / \mathrm{l}$ in men; b) independent of age; c) increased with obesity. Fasting plasma glucose of 7.0/ $7.8 \mathrm{mmol} / \mathrm{l}$ or more predicted a diabetic 2 -h plasma glucose with sensitivities of 49.0/29.8\% and specificities of 98.2/99.7\%, respectively.

Conclusion/interpretation. If fasting glucose is used alone, the $31 \%$ of diabetic subjects with a non-diabetic fasting glucose but a diabetic 2-h glucose, will not be diagnosed; impaired fasting glycaemia and impaired glucose tolerance do not identify the same people; the risk profile of people with impaired fasting glycaemia depends on 2-h glucose concentrations. Obesity is the main confounder in the association between fasting and 2-h glucose. [Diabetologia (1999) 42: 647-654]

Keywords Diabetes, diagnosis, diagnostic criteria, epidemiology, ROC-analysis, risk factors.
Received: 18 December 1998 and in revised form: 12 February 1999

Corresponding author: K. Borch-Johnsen, MD, Steno Diabetes Centre, Niels Steensens Vej 2, 2820 Gentofte, Denmark Abbreviations: FPG, fasting plasma glucose (mmol/l); $2 \mathrm{hPG}$, plasma glucose $(\mathrm{mmol} / \mathrm{l})$ at $2 \mathrm{~h}$ following an OGTT; ADA, American Diabetes Association; WHO, World Health Organisation; ROC-curve analysis, Receiver Operator Characteristics Curve analysis (Graphical presentation of the sensitivity and specificity of variable $\mathrm{X}$ as predictor of outcome $\mathrm{Y}$ ); IFG, impaired fasting glycaemia.

* see Acknowledgements
New diagnostic criteria for diabetes mellitus were approved by the American Diabetes Association (ADA) in 1997 [1] and in 1998 the World Health Organisation (WHO) Consultation published their provisional report [2]. The ADA Expert Committee and the WHO Consultation both recommend that for diagnosing diabetes, the cut-point for the fasting plasma glucose (FPG) should be lowered from 7.8 to $7.0 \mathrm{mmol} / \mathrm{l}$ but the concentration of 2-h plasma glucose (2hPG) following a 75-g oral glucose tolerance test (OGTT) should remain unchanged at $11.1 \mathrm{mmol} / \mathrm{l}$.

There were several reasons for these recommendations. Two cross sectional $[3,4]$ and one prospec- 
tive [5] study had shown that FPG in the interval 7.0 to $7.8 \mathrm{mmol} / \mathrm{l}$ was associated with an increased risk of microvascular retinal complications. One prospective study had shown that slightly elevated (but not diabetic) FPG values were associated with an increased mortality from coronary heart disease [6]. Several studies have shown that, at the time of clinical diagnosis of diabetes, the prevalence of microvascular and macrovascular complications may be as high as $30-40 \%$ [7-10] and the estimated median diabetes duration at the time of clinical diagnosis is more than 5 years [11]. Thus, the ADA Expert Committee and the WHO Consultation both recommended a lowering of the FPG value to define diabetes and, according to the WHO Consultation, $7.0 \mathrm{mmol} / \mathrm{l}$ was chosen "to represent a value which in most persons is of approximately equal diagnostic significance to that of the 2-h post-load concentration". Furthermore, to simplify the diagnosis and to facilitate earlier diagnosis, the ADA recommended the use of the fasting value as the primary diagnostic tool. In contrast the WHO Consultation advised retaining the 2-h post load measurement.

Previously, we have shown that despite a relatively small change in the overall prevalence of diabetes using only the $2 \mathrm{hPG}$ compared with only the FPG, there was a considerable change in the classification of people [12]. The aim of the present paper is to: 1 . Analyse whether a FPG value of $7.0 \mathrm{mmol} / \mathrm{l}$ has an "equal diagnostic significance" to the $2 \mathrm{hPG}$ of $11.1 \mathrm{mmol} / \mathrm{l}$. 2. Evaluate the potential effect of different stepwise screening strategies for diabetes based on measurement of FPG followed by a $2 \mathrm{hPG}$ if a patient has fasting hyperglycaemia. 3. Compare the classification of people in the two groups: impaired glucose tolerance (IGT) and impaired fasting glucose (IFG) and to evaluate the cardiovascular risk profile in the IFG group according to the 2-h glucose category, as cardiovascular disease is the leading cause of death in people with Type II (non-insulin-dependent) diabetes mellitus and IGT.

\section{Subjects and methods}

All centres in Europe with studies on the prevalence of diabetes mellitus in adults, either population based studies or studies in large representative samples of occupational groups, were invited to participate. This article includes data on $47396 \mathrm{sub}-$ jects (27 799 men and 19597 women) without previously diagnosed diabetes from 17 [13-29] population-based studies and 3 [30-32] in occupational groups. The design and data collection has been described in detail in a previous publication [12]; four new centres have been included in this analysis, from London, United Kingdom (the Goddinge Study) [26], Malta [27], Västerbotten, Sweden [28] and Iceland [29].

Each centre provided crude original data on their population including age, sex, date of examination, height, weight, status of known diabetes, glucose load ( $75 \mathrm{~g}$ for all except Iceland), fasting and 2-h post load glucose, blood specimen used, glucose assay and, where available, blood pressures (Korotkoff phase one and five), serum-cholesterol and smoking status (current, ex- or never smoker). Data from Iceland were analysed separately as they used a 50-g OGTT. Data were sent to the Diabetes and Genetic Epidemiology Unit of the National Public Health Institute in Helsinki, Finland. Data were analysed for each centre individually and then on a pooled basis (where possible).

When data were analysed by categories of glucose tolerance (normal, IFG, IGT, diabetes mellitus) all studies using a 75-g OGTT (all centres except Iceland) were included. The corresponding fasting values for glucose in plasma, serum, venous whole blood and capillary whole blood were: $6.1=6.1=5.6=5.6 \mathrm{mmol} / 1 ; \quad 7.0=7.0=6.1=6.1 \mathrm{mmol} / 1$ and $7.8=7.8=6.7=6.7 \mathrm{mmol} / \mathrm{l}$. For 2 -h post load concentrations, the corresponding values were: $7.8=7.8=6.7=7.8 \mathrm{mmol} / \mathrm{l}$; $11.1=11.1=10.0=11.1 \mathrm{mmol} / \mathrm{l}$ [2]. The analyses were based on individual glucose values given by the centres. As the centres had carried out their studies independently, there was no central laboratory nor central quality control of the glucose assays.

Chi-squared tests were used to test whether the classification according to fasting and 2-hour glucose concentrations was homogeneous between study centres, in sex-age specific strata.

For the receiver operator characteristics curve (ROC)analyses, only centres measuring plasma glucose concentrations were included due to the lack of conversion factors between glucose concentrations in plasma, serum, venous whole blood and capillary whole blood ROC-analysis [33] was used to identify an optimal FPG concentration which maximised the sensitivity and specificity with respect to the $2 \mathrm{hPG}$ of $11.1 \mathrm{mmol} / \mathrm{l}$. The sensitivity and specificity of a FPG of 7.0 and $7.8 \mathrm{mmol} / \mathrm{l}$ were also evaluated, as were the effects of sex, age and BMI.

The sensitivity and specificity of two stepwise screening strategies for diabetes and IGT in the population were evaluated; measurement of FPG in the entire population and an OGTT with a $2 \mathrm{hPG}$ only if the FPG was either more than $5.5 \mathrm{mmol} / \mathrm{l}$ or more than $6.0 \mathrm{mmol} / \mathrm{l}$. These values were chosen as a random plasma glucose less than $5.5 \mathrm{mmol} / \mathrm{l}$ which is stated as "Diabetes mellitus unlikely" by the WHO Consultation [2], and FPG of $6.1 \mathrm{mmol} / \mathrm{l}$ or more is the lower limit for IFG [1,2]. In both cases we estimated the percentage of the population needing an OGTT and the percentage of people with diabetes or IGT that would not be identified using the stepwise strategy.

The cardiovascular risk profile was studied in the IFG group, subdivided according to 2 -h glucose concentrations. Characteristics were compared using analysis of covariance, adjusted for age.

Data were analysed at the National Public Health Institute in Helsinki, using SPSS version 7.5.1 for Windows.

\section{Results}

The study included 18918 men [age, 53.1 years ( \pm 11.1$)$, means $( \pm \mathrm{SD})$; BMI, $\left.26.1 \mathrm{~kg} / \mathrm{m}^{2}( \pm 3.4)\right]$ and 10190 women [age, 53.7 years $( \pm 11.8)$; BMI, $\left.26.2 \mathrm{~kg} / \mathrm{m}^{2}( \pm 4.9)\right]$ all receiving a 75-g OGTT. Furthermore, data from Iceland are presented separately as they used a 50-g OGTT [8881 men; age, 52.2 years $( \pm 8.6)$, BMI, $25.7 \mathrm{~kg} / \mathrm{m}^{2}( \pm 3.4)$, and 9407 women; age: 53.7 years $( \pm 11.8)$, BMI, $\left.26.2 \mathrm{~kg} / \mathrm{m}^{2}( \pm 4.9)\right]$. Data on age, BMI, and glucose concentrations (fast- 
Table 1. Characteristics of subjects [mean (SD), or percentage] included in the DECODE Study, by sex (people with previously diagnosed diabetes are not included)

\begin{tabular}{|c|c|c|c|c|c|c|c|c|}
\hline \multirow[t]{2}{*}{ Population } & \multirow[t]{2}{*}{ No. } & \multirow[t]{2}{*}{ Age (years) } & \multirow{2}{*}{$\begin{array}{l}\text { BMI } \\
\left(\mathrm{kg} / \mathrm{m}^{2}\right)\end{array}$} & \multicolumn{2}{|c|}{ Blood pressure $(\mathrm{mm} \mathrm{Hg})$} & \multirow{2}{*}{$\begin{array}{l}\text { Cholesterol } \\
(\mathrm{mmol} / \mathrm{l})\end{array}$} & \multirow{2}{*}{$\begin{array}{l}\text { Smoker } \\
(\%)\end{array}$} & \multirow[t]{2}{*}{ Glucose $^{c}$} \\
\hline & & & & Systolic & Diastolic & & & \\
\hline \multicolumn{9}{|l|}{$\overline{\text { Men }}$} \\
\hline Vantaa, Finland & 244 & $71.7(0.5)$ & $26.8(3.7)$ & - & - & - & - & VWB \\
\hline Pieksämäkis, Finland & 249 & $43.1(5.7)$ & $28.2(3.6)$ & $142(18)$ & $87(12)$ & $5.8(1.1)$ & - & VWB \\
\hline \multicolumn{9}{|l|}{ Oulu, Finland } \\
\hline Middle-aged & 328 & $55.0(0)$ & $26.6(3.4)$ & $150(18)$ & $94(10)$ & $5.7(1.2)$ & 29.2 & CWB \\
\hline Newcastle, England & 403 & $54.7(12.7)$ & $26.3(3.9)$ & $134(22)$ & $80(12)$ & - & 29.5 & PG \\
\hline Goodinge, England & 454 & $54.7(10.3)$ & $25.5(4.1)$ & $121(20)$ & $72(12)$ & $6.3(1.2)$ & 41.2 & PG \\
\hline Zutphen, the Netherlands & 445 & $75.7(4.5)$ & $25.6(3.2)$ & $150(22)$ & $82(12)$ & $6.1(1.1)$ & 22.6 & PG \\
\hline Cremona, Italy & 735 & $56.7(10.4)$ & $26.6(3.6)$ & $145(20)$ & $81(12)$ & $6.0(1.1)$ & 32.5 & PG \\
\hline Malta & 754 & $50.0(13.1)$ & $27.1(4.3)$ & $137(20)$ & $84(11)$ & - & - & CWB \\
\hline FIN-MONICA, Finland & 893 & $54.6(5.9)$ & $27.8(3.8)$ & 144 (19) & $88(11)$ & $6.0(1.0)$ & 26.5 & PG \\
\hline Helsinki police, Finland & 1120 & $44.6(8.0)$ & $25.7(2.8)$ & $138(18)$ & $83(11)$ & $6.1(1.2)$ & 48.8 & VWB \\
\hline Telecom, France & 1355 & $43.6(9.9)$ & $24.8(3.0)$ & $133(16)$ & $79(12)$ & $6.2(1.1)$ & - & $\mathrm{PG}$ \\
\hline Paris, France & 7034 & $49.0(2.0)$ & $26.0(3.3)$ & $144(22)$ & $81(13)$ & $5.7(1.1)$ & 64.0 & PG \\
\hline Iceland $^{\mathrm{a}}$ & 8881 & $52.2(8.6)$ & $25.7(3.4)$ & - & - & - & 54.1 & CWB \\
\hline Overall $^{\mathrm{b}}$ & 18918 & $53.1(11.1)$ & $26.1(3.4)$ & $141(21)$ & $82(12)$ & $6.0(1.2)$ & 44.0 & \\
\hline \multicolumn{9}{|l|}{ Women } \\
\hline POL-MONICA, Poland & 187 & $57.7(8.5)$ & $29.3(4.9)$ & $138(20)$ & $81(11)$ & $5.9(1.0)$ & 6.4 & Serum \\
\hline Pieksämäkis, Finland & 264 & $43.1(5.9)$ & $28.1(5.7)$ & $135(19)$ & $82(10)$ & $5.3(1.0)$ & - & VWB \\
\hline Vantaa, Finland & 307 & $71.8(0.4)$ & $27.4(4.6)$ & - & - & - & - & VWB \\
\hline Newcastle, England & 376 & $54.7(12.3)$ & $26.4(5.0)$ & $128(24)$ & $71(11)$ & - & 26.2 & PG \\
\hline \multicolumn{9}{|l|}{ Oulu, Finland } \\
\hline Middle-aged & 431 & $55.0(0)$ & $26.5(4.3)$ & $143(18)$ & $89(10)$ & $5.9(1.3)$ & 18.8 & CWB \\
\hline Elderly & 189 & $76.3(4.8)$ & $28.8(4.8)$ & $162(27)$ & $81(11)$ & $4.2(0.3)$ & 3.3 & CWB \\
\hline Iceland $^{\mathrm{a}}$ & 9407 & $52.8(8.5)$ & $25.0(4.2)$ & - & - & $6.3(1.3)$ & 40.5 & CWB \\
\hline Overall $^{\mathrm{b}}$ & 10190 & $53.7(11.8)$ & $26.2(4.9)$ & $133(22)$ & $79(13)$ & $6.4(1.4)$ & 24.5 & \\
\hline
\end{tabular}

a 90-min glucose, 50-g glucose loading

${ }^{\mathrm{c}} \mathrm{PG}=$ Plasma glucose, Serum $=$ Serum glucose, $\mathrm{VWB}=\mathrm{Ve}-$

${ }^{\mathrm{b}}$ Not including Iceland nous whole blood glucose, $\mathrm{CWB}=$ Capillary whole blood glucose

ing and 2-h) were available in all populations and data on BP, serum-cholesterol and smoking (current, ex- or never smoker) were available in the majority of studies (Table 1).

Association between fasting and 2-h plasma glucose values. The ROC-curves did not differ between the sexes (Fig. 1) but the optimal cut-point was higher in men than in women $(6.4 \mathrm{vs} 5.8 \mathrm{mmol} / \mathrm{l}$, Table 2$)$. Subdividing the group into four age strata $(<50$ years, 50-64 years, 65-74 years and $\geq 75$ years) we found no difference in the optimal FPG cut-point (range $6.0-6.3 \mathrm{mmol} / \mathrm{l})$. In obese people (BMI $\geq 30 \mathrm{~kg} / \mathrm{m}^{2}$ ) the optimal FPG cut-point was $6.6 \mathrm{mmol} / \mathrm{l}$, lower than the diagnostic value for diabetes of $7.0 \mathrm{mmol} / \mathrm{l}$, with a sensitivity of $75 \%$ and a specificity of $91 \%$ (Table 2). In people of normal weight, the FPG cutpoint decreased to $5.8 \mathrm{mmol} / \mathrm{l}$ and both sensitivity and specificity decreased greatly (Fig.2). Men and women had similar mean BMI and the optimal cutpoint decreased with decreasing BMI in both sexes (data not shown).

Among people with $2 \mathrm{hPG} 11.1 \mathrm{mmol} / \mathrm{l}$ or more (diabetic) more than $50 \%$ had a FPG less than $7.0 \mathrm{mmol} / \mathrm{l}$ and $31 \%$ had a normal FPG according to the revised criteria (Fig. 3). Thus, almost one in three people diabetic according to the $2 \mathrm{hPG}$ would be declared normal if only FPG was available. Among peo- 


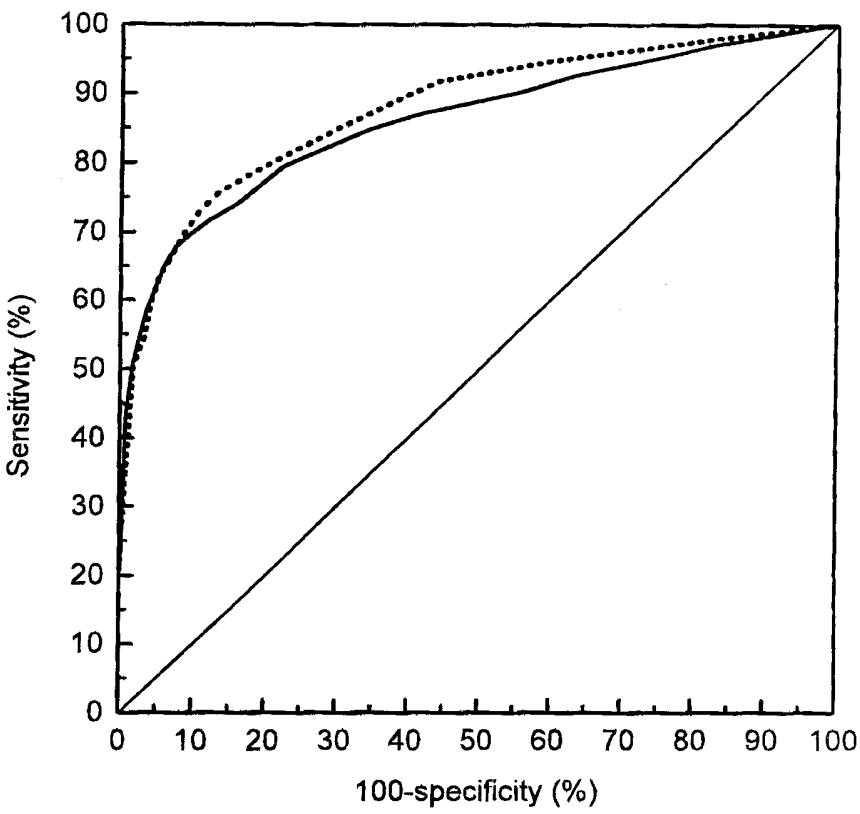

Fig. 1. Receiver Operator Characteristic (ROC) curves for fasting venous plasma glucose predicting a 2-h plasma glucose of $11.1 \mathrm{mmol} / \mathrm{l}$ or more in the $14291 \mathrm{men}$ (__ ) and the 6857 women $(\ldots . .$.$) . The DECODE Study$

Table 2. Optimal fasting plasma glucose (mmol/l) cutpoints corresponding to a 2 -h plasma glucose concentration $11.1 \mathrm{mmol} / \mathrm{l}$ or more, according to sex and BMI. People without previously diagnosed diabetes and with glucose from plasma samples. The DECODE Study

\begin{tabular}{lrlll}
\hline & No. & $\begin{array}{l}\text { Fasting } \\
\text { plasma glucose } \\
(\mathrm{mmol} / \mathrm{l}) \\
\text { cut-point }\end{array}$ & $\begin{array}{l}\text { Sensitivity } \\
\%\end{array}$ & $\begin{array}{l}\text { Specificity } \\
\%\end{array}$ \\
\hline Sex & & & & \\
$\quad$ Men & 14921 & 6.4 & 67.8 & 92.5 \\
Women & 6857 & 5.8 & 75.7 & 86.6 \\
Both & 21778 & 6.2 & 69.6 & 90.0 \\
BMI $\left(\mathrm{kg} / \mathrm{m}^{2}\right)$ & & & & \\
$<25$ & 9334 & 5.8 & 56.3 & 86.1 \\
$25-29$ & 9507 & 6.3 & 72.8 & 90.5 \\
$\geq 30$ & 2808 & 6.6 & 75.4 & 91.1 \\
\hline
\end{tabular}

ple with $2 \mathrm{hPG}$ in the IGT range, nearly $70 \%$ had normal FPG whereas $23 \%$ had FPG in the IFG range.

Among people with FPG in the IFG range, $7 \%$ were diabetic on the 2 -h value but $29 \%$ had values in the IGT range (Fig. 4) and two thirds had a normal $2 \mathrm{hPG}$. People who had a diabetic FPG based on the former criteria ( $\geq 7.8 \mathrm{mmol} / \mathrm{l}$ ) or only according to the new diagnostic criteria $(7.0-7.7 \mathrm{mmol} / \mathrm{l})$ had normal $2 \mathrm{hPG}$ values in $7 \%$ and $35 \%$ of instances, respectively.

Fasting and 2-h post load plasma glucose concentrations and screening strategies. The percentage of sub-

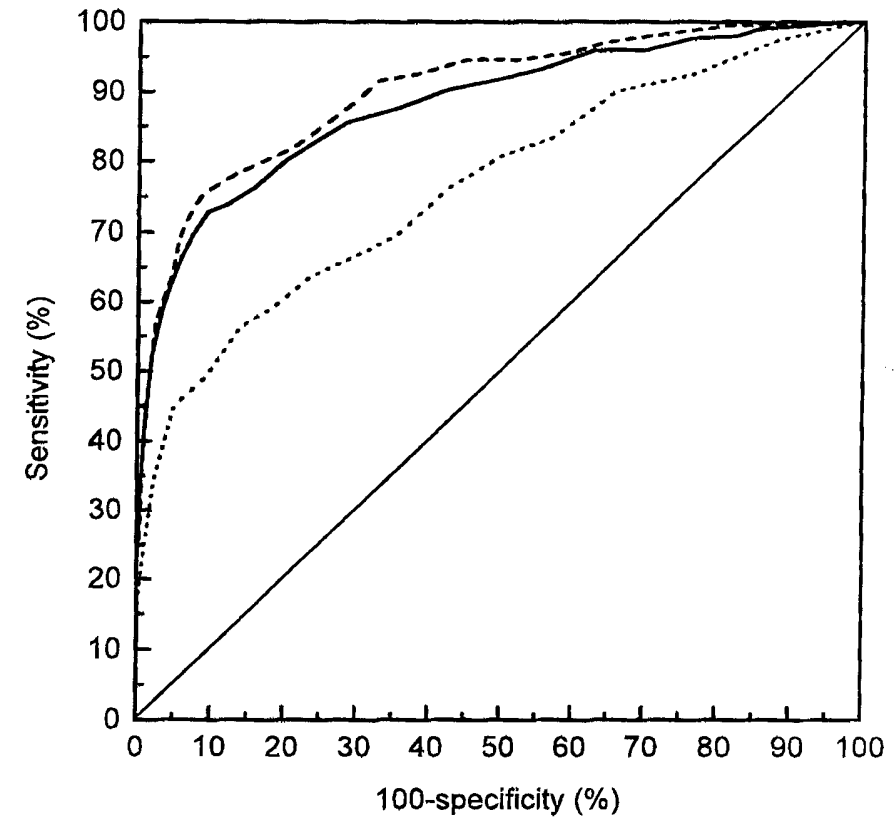

Fig. 2. Receiver Operator Characteristic (ROC) curves for fasting venous plasma glucose predicting a 2 -h plasma glucose of $11.1 \mathrm{mmol} / \mathrm{l}$ or more in the 9334 lean $\left(\mathrm{BMI}<25 \mathrm{~kg} / \mathrm{m}^{2}\right)$ $(\ldots \ldots), 9507$ overweight (BMI 25-29 kg/m ${ }^{2}$ ) (_ $)$ and 2808 obese $\left(\mathrm{BMI} \geq 30 \mathrm{~kg} / \mathrm{m}^{2}\right)(---)$ people. The DECODE Study

jects with previously undiagnosed diabetes (equivalent to $\mathrm{FPG} \geq 7.0 \mathrm{mmol} / \mathrm{l}$ and/or $2 \mathrm{hPG} \geq 11.1 \mathrm{mmol} / \mathrm{l}$ ) was $5.7 \%$, and $11.9 \%$ had IGT (equivalent to FPG $<7.0 \mathrm{mmol} / \mathrm{l}$ and 2-h glucose 7.8 to $11.0 \mathrm{mmol} / \mathrm{l}$ ) (Table 3). This classification was not homogeneous between centres, in sex and age specific strata (all $p<0.001)$.

If a stepwise strategy used the $2 \mathrm{hPG}$ only in people with FPG more than $5.5 \mathrm{mmol} / \mathrm{l}$ and less than $7.0 \mathrm{mmol} / 1$ (the lower level for diabetes), $46 \%$ of the population would need an OGTT. This strategy would identify $93 \%$ of all people with diabetes based on $2 \mathrm{hPG}$ of $11.1 \mathrm{mmol} / \mathrm{l}$ or more and $69 \%$ of all with IGT. If a stepwise strategy where an OGTT was used only if FPG was 6.1 to $6.9 \mathrm{mmol} / \mathrm{l}$ (the IFG group) only $12 \%$ would need an OGTT but this strategy would only identify $82 \%$ of people with diabetes and $29 \%$ of those with IGT.

Comparison of impaired glucose tolerance with impaired fasting glucose. Among the 29108 people without previously diagnosed diabetes, 3119 had IFG (Table 3). Among these, $65 \%$ had normal 2-h glucose concentrations and $7 \%$ had a diabetic 2 -h glucose. Among the 3833 subjects with 2-h glucose in the IGT range, $67 \%$ had normal fasting glucose, while $23 \%$ had fasting values in the IFG range.

The distribution of cardiovascular risk factors in the IFG group depended on the 2-h glucose concentrations (Table 4). Systolic and diastolic blood pressure increased with increasing 2-h glucose for peo- 


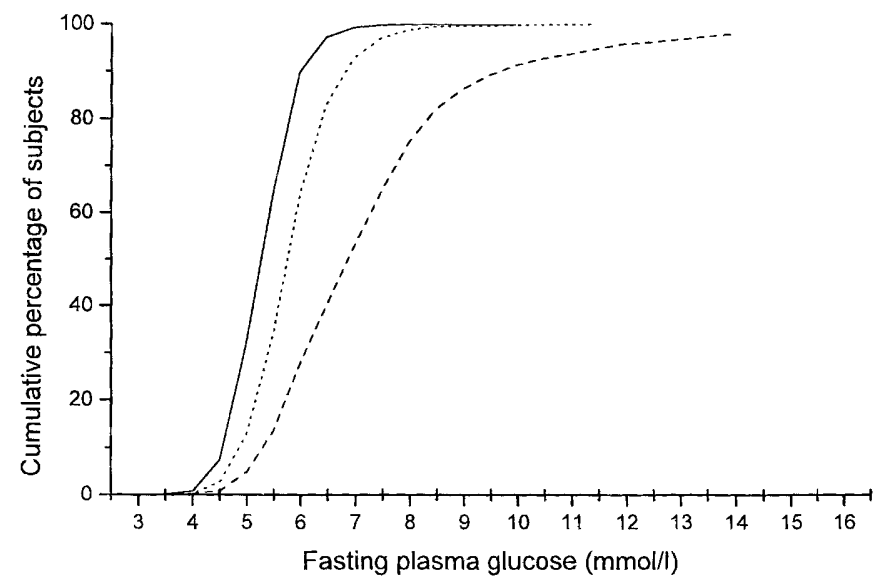

Fig. 3. Cumulative distribution of fasting plasma glucose for people with normal, less than $7.8 \mathrm{mmol} / \mathrm{l}$, (__ $)$, impaired glucose tolerance, $7.8-11.0 \mathrm{mmol} / \mathrm{l},(\ldots \ldots \ldots)$ and diabetes, more than $11.1 \mathrm{mmol} / \mathrm{l},(---)$ according to 2 -h plasma glucose concentrations. The DECODE Study

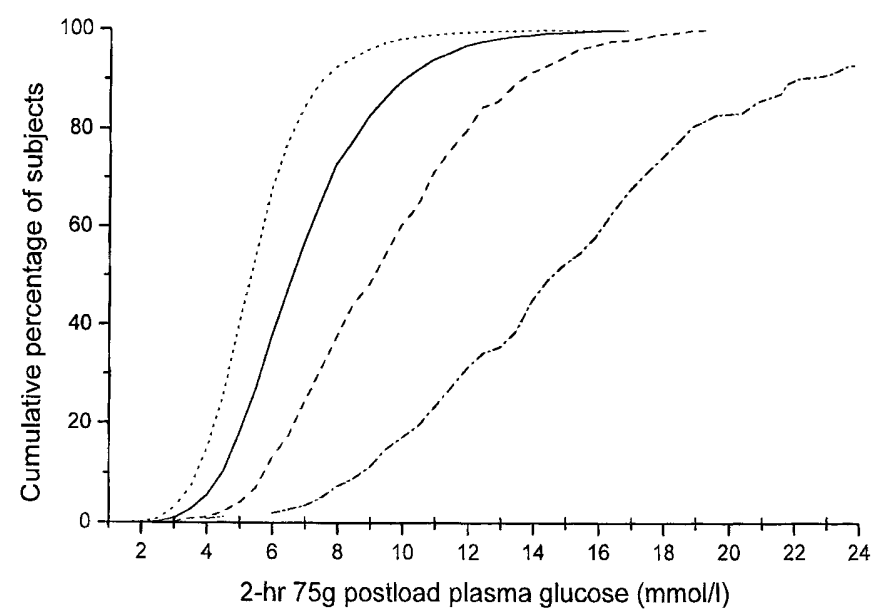

Fig.4. Cumulative distribution of 2 -h plasma glucose for people with normal, less than $6.1 \mathrm{mmol} / \mathrm{l},(\ldots \ldots \ldots)$, impaired fasting glycaemia, $6.1-6.9 \mathrm{mmol} / \mathrm{l}$, (__ $)$, diabetes with FPG 7.0-7.7 mmol/l (- - ) or diabetes with FPG $\geq 7.8 \mathrm{mmol} / \mathrm{l}$ $(-\cdot-\cdot \cdot-)$, according to fasting plasma glucose concentrations. The DECODE Study

ple with IFG, except in women aged 60 years and over. Body mass index increased with increasing 2-h glucose except in the older men and for serumcholesterol, an effect was only seen in the older women.

\section{Discussion}

The main difference in the changes in diagnostic criteria defined by the ADA Expert Group and those recommended by the WHO Consultation is that the ADA strongly recommended that the FPG could be used on its own and that in general the $2 \mathrm{hPG}$ need not be used. In contrast, the WHO Consultation retained the $2 \mathrm{hPG}$ and suggested using the FPG alone in epidemiological surveys only when circumstances prevent use of the OGTT $[2,34]$. We have previously shown that a change from the use of the 2-h glucose alone to the use of the fasting glucose alone for the diagnosis of diabetes in population surveys would induce quite dramatic changes in the prevalence of diabetes in some European populations [12]. The magnitude of the change was influenced by age and obesity in the populations studied. For the overall diabetes prevalence in Europe, a change in method from defining diabetes by the $2 \mathrm{hPG}$ of $11.1 \mathrm{mmol} / \mathrm{l}$ or more to FPG of $7.0 \mathrm{mmol} / \mathrm{l}$ or more would increase the prevalence of diabetes from $7.2 \%$ to $7.7 \%$ but with a range between populations from a $26 \%$ decrease to a $51 \%$ increase. Among the 1665 people diagnosed diabetic either based on the FPG or on the $2 \mathrm{hPG}$, only $489(29 \%)$ had FPG of 7.0 or more and $2 \mathrm{hPG}$ of $11.1 \mathrm{mmol} / \mathrm{l}$ or more.

The first aim of the present study was to evaluate the statement by the ADA Expert Committee and the WHO Consultation that a FPG of $7.0 \mathrm{mmol} / \mathrm{l}$ is "of approximately equal diagnostic significance" to that of a $2 \mathrm{hPG}$ of $11.1 \mathrm{mmol} / \mathrm{l}$. We found that the FPG concentration corresponding to a $2 \mathrm{hPG}$ value of $11.1 \mathrm{mmol} / \mathrm{l}$ with maximised sensitivity and specificity was $6.4 \mathrm{mmol} / \mathrm{l}$ in men and $5.8 \mathrm{mmol} / \mathrm{l}$ in women. These fasting values are lower than those reported from the Pima Indians [35], the Pacific Island populations [36] and the NHANES III study [1]. We show that the FPG value optimising sensitivity and specificity was dependent on BMI, increasing from $5.8 \mathrm{mmol} / \mathrm{l}$ in lean people $\left(\mathrm{BMI}<25 \mathrm{~kg} / \mathrm{m}^{2}\right)$ to $6.6 \mathrm{mmol} / 1$ in obese people $\left(\mathrm{BMI} \geq 30 \mathrm{~kg} / \mathrm{m}^{2}\right)$. The mean BMI in this study was $25.9 \mathrm{~kg} / \mathrm{m}^{2}$ in contrast to that of Pima Indians of $31.6 \mathrm{~kg} / \mathrm{m}^{2}$ and Micronesians from Nauru, $33 \mathrm{~kg} / \mathrm{m}^{2}$ [37]. This difference in obesity may explain the difference between the results of our study and those quoted by the ADA Expert Committee [1].

We found that a cut-point of $7.8 \mathrm{mmol} / \mathrm{l}$ is highly specific $(99.7 \%)$ in identifying people without a diabetic $2 \mathrm{hPG}$ but the sensitivity is low (20\%). Lowering the diagnostic threshold for FPG to $7.0 \mathrm{mmol} / \mathrm{l}$ increased the sensitivity to $49 \%$ without any major loss in specificity $(98.2 \%)$. Thus, lowering the diagnostic FPG from 7.8 to $7.0 \mathrm{mmol} / \mathrm{l}$ would be an advantage in terms of sensitivity but the low sensitivity of only $49 \%$ raises the need for a confirmatory test, for which the 2-h post load glucose concentration would be a rational choice.

The high prevalence of microvascular [7-10] and macrovascular $[38,39]$ complications and the estimated median diabetes duration of at least 4 to 7 years before clinical diagnosis of diabetes [11] were the main reasons for the ADA Expert Committee recommending screening for diabetes in everybody 
Table 3. Distribution of the 29108 people without previously diagnosed diabetes, according to fasting and 2-h glucose categories. The DECODE Study

\begin{tabular}{llllll}
\hline & & \multicolumn{2}{l}{ 2-h glucose } & Total \\
\cline { 3 - 5 } & & Normal & IGT & Diabetic & \\
\hline \multirow{3}{*}{$\begin{array}{l}\text { Fasting } \\
\text { glucose }\end{array}$} & IFG & 21968 & 2562 & 316 & 24846 \\
& & $(75.5 \%)$ & $(8.8 \%)$ & $(1.1 \%)$ & $(85.4 \%)$ \\
& \multirow{2}{*}{ Diabetic } & 2020 & 893 & 206 & 3119 \\
Total & & $(0.9 \%)$ & $(3.1 \%)$ & $(0.7 \%)$ & $(10.7 \%)$ \\
& & 24264 & 378 & 489 & 1143 \\
& & $(83.4 \%)$ & $(13.2 \%)$ & $(1.7 \%)$ & $(3.9 \%)$ \\
& & & & & \\
\hline
\end{tabular}

above the age of 45 years [1]. As we have shown previously [12], only $48 \%$ of previously undiagnosed diabetic people with a $2 \mathrm{hPG}$ of $11.1 \mathrm{mmol} / \mathrm{l}$ or more also have a FPG of $7.0 \mathrm{mmol} / \mathrm{l}$ or more. The second aim of this analysis therefore was to test the usefulness of different stepwise screening models for diabetes using a FPG as a screening variable followed by 2 -h OGTT only if the FPG was above a specified level, assuming that our DECODE population is representative of a general European population. The potential advantage of this strategy would be that the number of glucose measurements could be reduced (reducing the costs and time related to the screening process). We analysed FPG concentrations of 5.5 and $6.0 \mathrm{mmol} / \mathrm{l}$, as cut-points for proposing a $2-\mathrm{h}$ OGTT. Both these procedures would identify the majority of the diabetic people $(93 \%$ and $82 \%$, respectively) but neither of these procedures would have sufficient sensitivity to detect people with IGT, as they would only detect $69 \%$ and $29 \%$ of such people. People with IGT may be the most important target for future interventions to prevent development of overt diabetes. One recent Chinese study has shown that changes in lifestyle may reduce the progression rate to diabetes by $35-40 \%$ [40] and several ongoing trials are testing pharmacological and non-pharmacological prevention strategies (Diabetes Prevention Programme in the USA, STOP-NIDDM trial in Canada, DPS-study in Finland, EDIPS-study in Europe). It may be possible to develop screening procedures based on FPG and $\mathrm{HbA}_{1 \mathrm{c}}$ that would also increase the sensitivity for detection of people with IGT [41, 42] but in our study we did not have $\mathrm{HbA}_{1 \mathrm{c}}$ measurements. Future studies should specifically test these possibilities.

In the revised diagnostic criteria for diabetes, the FPG concentration was lowered because the prevalence of retinopathy started to increase at FPG concentrations close to $7.0 \mathrm{mmol} / \mathrm{l}[1]$. At the same time a new category was introduced, impaired fasting glycaemia [1]. The ADA Expert Group and the WHO Consultation [2] both state that the IFG and IGT groups may not identify the same people but they suggest that both are high risk groups for the devel-

Table 4. Age adjusted mean values of cardiovascular risk factors in the 3119 people with impaired fasting glycaemia, classified according to 2-h glucose concentrations. The DECODE Study

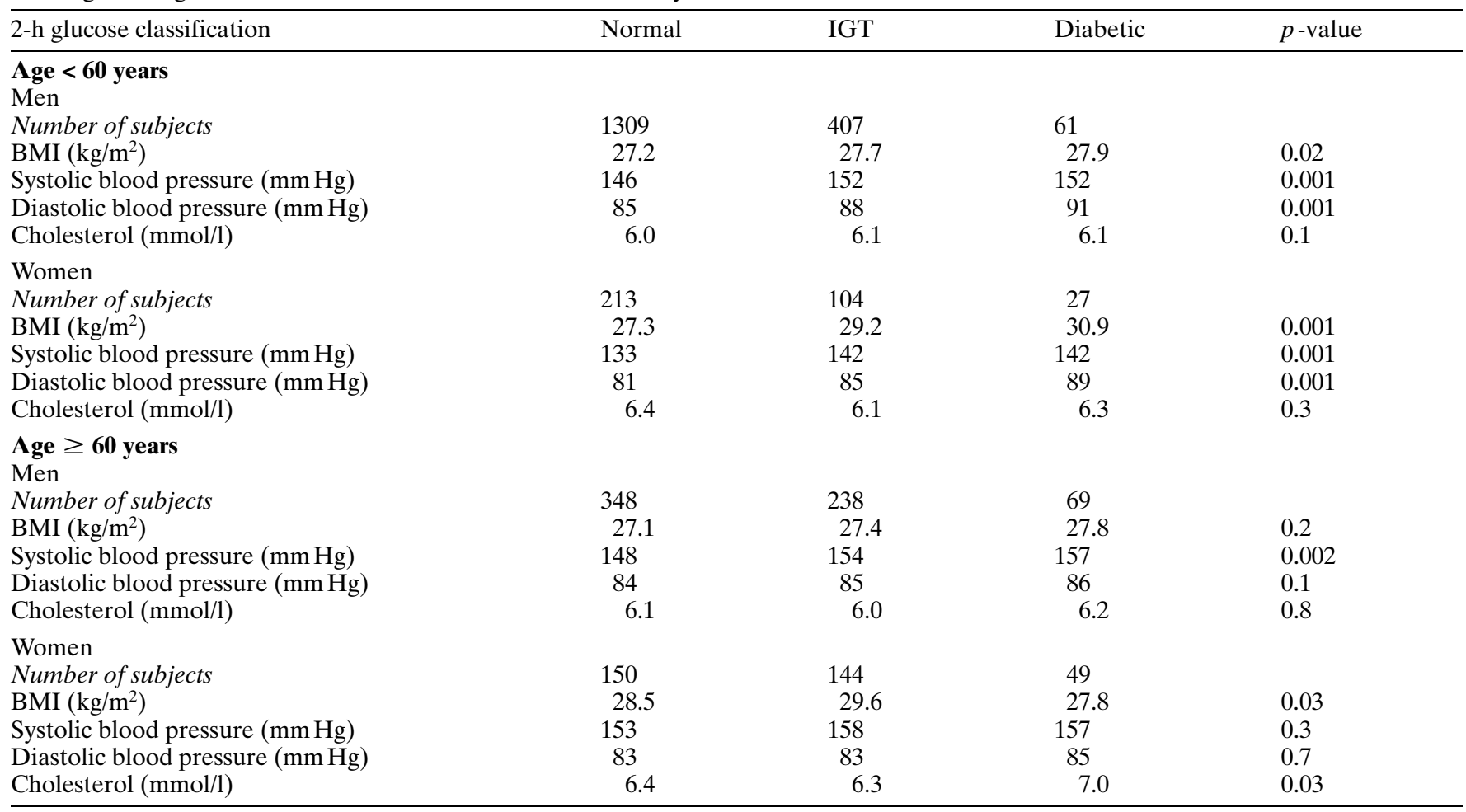


opment of diabetes. Although the two groups are almost of equal size, the people classified as IGT are not the same as those classified as IFG. Therefore, we compared the cardiovascular risk profile within the IFG group, subdivided on the basis of 2-h glucose concentration as normal, IGT or diabetic. Blood pressure and BMI generally increased with increasing 2-h glucose values. Based on this finding we would expect that people with isolated IFG (high fasting glucose and normal post load glucose) would have a lower mortality and lower risk of developing cardiovascular disease. Thus it is questionable whether it is rational to establish IFG as a separate, new clinical entity. Before doing so it should at least be shown that isolated IFG is associated with increased mortality or morbidity from cardiovascular disease, or that IFG has an acceptable sensitivity and specificity in predicting the subsequent development of diabetes. Otherwise we will be labelling people as being at high risk without any valid reason which raises ethical problems.

In conclusion, in 1997 the ADA revised their diagnostic criteria for diabetes, lowering the FPG value from 7.8 to $7.0 \mathrm{mmol} / \mathrm{l}$, introducing a new category, (IFG) and recommending the use of FPG alone for the diagnosis of diabetes. In 1998 the WHO Consultation followed the ADA with respect to the two first recommendations, while they retained the use of the 75-g OGTT and the $2 \mathrm{hPG}$ for diagnostic purposes. We show that if the FPG were used alone, $31 \%$ of all people with diabetes (based on fasting or 2-h glucose concentrations or both) will remain undiagnosed. Furthermore, the sensitivity and specificity of the FPG concentration in detecting a diabetic $2 \mathrm{hPG}$ depends on the BMI. This may explain the difference between our results and data from the United States and the Pacific Islands and makes it even more important to analyse the impact of using only the FPG for diagnosing diabetes in other regions including Asia. Finally, this study shows that fasting glucose concentrations are of very limited help in identifying people with IGT, a group where prevention of progression to overt diabetes seems to be possible. For these reasons we would strongly recommend the continued use of the $2 \mathrm{hPG}$ in the diagnosis of diabetes. Based on the ROC-curves as well as the cardiovascular-risk profile there is, however, good support for the lowering of the FPG value diagnostic for diabetes from 7.8 to $7.0 \mathrm{mmol} / \mathrm{l}$.

Acknowledgements. Novo Nordisk, Bagsvaerd, Denmark supported this analysis by a fellowship for Dr. Q. Qiao for data analysis.

The DECODE Study (Diabetes Epidemiology: Collaborative analysis of Diagnostic Criteria in Europe) was undertaken upon the initiative of the European Diabetes Epidemiology Study Group (Chairman: K. Borch-Johnsen; Vice-chairman: A. Neil; Secretary: B. Balkau).
Investigators and Study Centres included in this analysis Denmark: Glostrup Population Studies. S. Larsen, K. BorchJohnsen, Centre of Preventive Medicine, Glostrup

Finland: Pieksämäki Study. M. Vanhala, Pieksämäki Community Health Centre, Pieksämäki

East-West Finland Study. A. Nissinen, J. Pekkanen, J. Tuomilehto, Department of Epidemiology and Health Promotion, National Public Health Institute, Helsinki

Oulu. S. Keinänen-Kiukaanniemi, U. Rajala, L. Hiltunen, Q. Qiao, S. Liisa Kivelä, Department of Public Health Science, University of Oulu

FIN-MONICA (Provinces of Kuopio and North Karelia, Tur$\mathrm{ku}$ and Helsinki areas). J. Tuomilehto, P. Jousilahti, J. Lindström, Department of Epidemiology and Health Promotion, National Public Health Institute, Helsinki

Helsinki Policemen Study. M. Pyörälä, K. Pyörälä, Department of Medicine, University of Kuopio

Vantaa Study. R. Tilvis, S. Sairanen, J. Tuomilehto, Division of Geriatrics, Department of Medicine, University of Helsinki

France: Paris Prospective Study. B. Balkau, E. Eschwege, INSERM U258, Villejuif

TELECOM. D. Simon, INSERM U258, Villejuif

Iceland: The Reykjavik Study. G. Sigurdsson, Dept. Medicine, Reykjavik Hospital, University of Iceland

Italy: Cremona Study. G. Gallus, P. Garancini, Epidemiology Unit, S. Raffaele Institute, Milan

Malta: The Malta Study. A. Schranz, Diabetes Clinic, St. Lukes Hospital, M'Gania

The Netherlands: The Hoorn Study. R. J. Heine, J. M. Dekker, Inst. Res. Extramural Medicine, Vrije University, Amsterdam The Zutphen Study. E. Feskens, Institute of Public Health, Bilthoven

Poland: POL-MONICA Study (Krakow). A. Pajak, Department of Clinical Epidemiology and Population Studies, Institute of Public Health, Collegium Medicum, Jagiellonian University, Krakow

Sweden: Uppsala Study. H. Lithell, B. Zethelius, Department of Geriatrics, University of Uppsala

The Västerbotten Study. M. Peltonen, K. Asplund, Dept Medicine, University of Umeå

United Kingdom: Newcastle Heart Project. N. Unwin, N. Ahmad, K. G. M. M. Alberti, Departments of Medicine and Epidemiology and Public Health, University of Newcastle

The Goodinge Study. J.S. Yudkin, M. Gould, A. Haines, Centre for Diabetes and Cardiovascular Risk and Dept. of Primary Health Care, University College London Medical School

Secretariat: K. Borch-Johnsen, Steno Diabetes Centre, Gentofte, Denmark; J. Eriksson, Q. Qiao, J. Tuomilehto, Department of Epidemiology and Health Promotion, National Public Health Institute, Helsinki

Data analysis: Q. Qiao, Department of Epidemiology and Health Promotion, National Public Health Institute, Helsinki, Finland; B. Balkau, INSERM U258, Villejuif, France

Writing Committee: K. Borch-Johnsen, Steno Diabetes Centre, Gentofte, Denmark; B. Balkau, INSERM U258, Villejuif, France; J. Tuomilehto and Q. Qiao, Department of Epidemiology and Health Promotion, National Public Health Institute, Helsinki 


\section{References}

1. The Expert Committee on the diagnosis and classification of diabetes mellitus (1997) Report of the Expert Committee on the diagnosis and classification of diabetes mellitus. Diabetes Care 20: 1183-1197

2. Alberti KGMM, Zimmet PZ for the WHO Consultation (1998) Definition, diagnosis and classification of diabetes mellitus and its complications. Part 1: diagnosis and classification of diabetes mellitus. Provisional report of a WHO Consultation. Diabet Med 15: 539-553

3. Engelgau MM, Thompson TJ, Herman WH et al. (1997) Comparison of fasting and 2-hour glucose and $\mathrm{HbA} 1 \mathrm{c}$ levels for diagnosing diabetes: diagnostic criteria and performance revisited. Diabetes Care 20: 785-791

4. Harris MI, Eastman RC, Cowie CC, Flegal KM, Eberhardt MS (1997) Comparison of diabetes diagnostic categories in the U.S. population according to 1997 American Diabetes Association and 1980-85 world health organisation diagnostic criteria. Diabetes Care 20: 1859-1862

5. McCance D, Hanson RL, Pettitt DL, Bennett PH, Hadden DR, Knowler WC (1997) Diagnosing diabetes mellitus - do we need new criteria? Diabetologia 40: 247-255

6. Charles MA, Balkau B, Vauzelle-Kervroedan F, Thibult N, Eschwege E (1996) Revision of diagnostic criteria for diabetes. Lancet 348: 1657-1658

7. Klein R, Klein BEK, Moss SE, Davis MD, DeMetz DL (1984) The Wisconsin Epidemiologic Study of Diabetic Retinopathy. III. Prevalence and Risk of Diabetic Retinopathy when age at diagnosis is 30 or more years. Arch Opthalmol 102: 527-532

8. Aldington SJ, Kohner EM, Nugent A (1987) Retinopathy at entry in the United Kingdom prospective diabetes study (UKPDS) of maturity onset diabetes. Diabetic Med 4: 355

9. UKPDS Group (1990) UK Prospective Diabetes Study 6. Complications in newly diagnosed Type 2 diabetic patients and their association with different clinical and biochemical risk factors. Diabetes Research 13: 1-11

10. Fabre J, Balant LP, Dayer PG, Fox HM, Verner AT (1982) The kidney in maturity onset diabetes mellitus, a clinical study of 510 patients. Kidney Int 21: 730-738

11. Harris MI, Klein R, Welborn TA, Knuiman MW (1992) Onset of NIDDM occurs at least 4-7 yr before clinical diagnosis. Diabetes Care 15: 815-819

12. The DECODE-study group on behalf of the European Diabetes Epidemiology Study Group (1998) Will new diagnostic criteria for diabetes mellitus change phenotype of patients with diabetes? BMJ 317: 371-375

13. Skarfors ET, Selinius KI, Lithell HO (1991) Risk factors for developing non-insulin dependent diabetes mellitus: a 10 year follow-up of men in Uppsala. BMJ 303: 755-760

14. Sygdom og Sundhed, Befolkningsunders $\varnothing$ gelserne i Glostrup (1987) In: Hagerup L (ed) UNI-C Publishers, Aarhus, Denmark

15. Stengard JH, Pekkanen J, Tuomilehto J et al. (1993) Changes in glucose tolerance among elderly Finnish men during a five-year follow-up: the Finnish cohorts of the Seven Countries Study. Diabet Metab 19: 121-129

16. Feskens EJM, Kromhout D (1994) Hyperinsulinemia, risk factors and coronary heart disease. Atherioscler Thromb 14: 1641-1647

17. Garancini MP, Calori G, Ruotolo G et al. (1995) Prevalence of NIDDM and impaired glucose tolerance in Italy: an OGTTbased population study. Diabetologia 38: 306-313

18. Mooy JM, Grootenhuis PA, de Vries Het al. (1991) Prevalence and determinants of glucose intolerance in a Dutch Caucasian Population. The Hoorn Study. Diabetes Care 18: 1270-1273

19. Vanhala MJ, Kumpusalo EA, Pitkäjärvi TK, Takala JK (1997) "Metabolic syndrome" in a middle-aged Finnish population. J Cardiovascular Risk 4: 291-295

20. Vartiainen E, Puska P, Jousilahti P, Korhonen HJ, Tuomilehto J, Nissinen A (1994) Twenty-year trends in coronary risk factors in North Karelia and in other areas of Finland. Int J Epidemiol 23: 495-504
21. Unwin N, Harland J, White M (1997) Body mass index, waist circumference, waist-hip ratio, and glucose intolerance in Chinese and Europid adults in Newcastle, UK. J Epidemiol Community Health 51: 160-166

22. Rajala U, Keinänen-Kiukaanniemi S, Uusimäki A, Reijula K, Kivelä SL (1995) Prevalence of diabetes mellitus and impaired glucose tolerance in a middle-aged Finnish population. Scand J Prim Health Care 13: 222-228

23. Pajak A (1995) Insulin sensitivity and coronary heart disease risk factors in a population based sample. XVII Congress of the European Society of Cardiology. European Heart Journal 16 [Suppl]:143

24. Lindberg O, Tilvis RS, Strandberg TE et al. (1997) Elevated fasting plasma insulin in a general aged population: an innocent companion of cardiovascular diseases. J Amer Geriatr Soc 45: 407-412

25. Hitunen L, Luukinen H, Koski K, Kivela SL (1994) Prevalence of diabetes mellitus in an elderly Finnish population. Diabet Med 11: 241-249

26. Gould MM, Mohamed-Ali V, Goubet SA, Yudkin JS, Haines AP (1993) Microalbuminuria: associations with height and sex in non-diabetic subjects. BMJ 306: 240-242

27. Schranz A, Tuomilehto J, Marti B, Jarrett RJ, Grabauskas V, Vassallo A (1991) Low physical activity and worsening of glucose tolerance: results from a 2 year follow-up of a population sample in Malta. Diabetes Res Clin Pract 11: 127-136

28. Stegmayr B, Asplund K (1995) Diabetes as a risk factor for stroke. A population perspective. Diabetologia 38: 1061-1068

29. Vilbergsson S, Sigurdsson G, Sigvaldason H, Hreidarsson AB, Sigfusson N (1997) Prevalence and incidence of NIDDM in Iceland: evidence for stable incidence among men and women 1967-1991. The Reykjavik Study. Diabet Med 14: 491-498

30. Fontbonne A, Papoz L, Eschwege E, Roger M, Saint-Paul M, Simon D (1992) Features of insulin-resistance syndrome in men from French Caribbean islands. The Telecom Study. Diabetes 41: 1385-1389

31. Pyörälä K, Savolainen E, Lehtovirta E, Punsar S, Sittanen P (1979) Glucose tolerance and coronary heart disease: Helsinki Policemen Study. J Chron Dis 32: 729-745

32. Balkau B, Eschwege E, Papoz L et al. (1993) Risk factors for early death in non-insulin dependent diabetes and men with known glucose tolerance status. BMJ 307: 295-299

33. Hanley JA, McNeil BJ (1982) The meaning and use of the area under a receiver operating characteristic (ROC) curve. Radiology 143: $29-36$

34. Albert KGGM, Zimmet P (1998) New diagnostic criteria and classification of diabetes - again? [editorial] Diabet Med 15: $535-536$

35. McCance DR, Hanson RL, Charles MA et al. (1994) Comparison of tests for glycated haemoglobin and fasting and two hour plasma glucose concentrations as diagnostic methods for diabetes. BMJ 308: 1323-1328

36. Finch CF, Zimmet PA, Alberti KGMM (1990) Determining diabetes prevalence: a rational basis for the use of fasting plasma glucose concentrations? Diabet Med 7: 603-610

37. Hodge AM, Dowse GK, Zimmet PZ (1993) Diet does not predict incidence or prevalence of non-insulin-dependent diabetes in Nauruans. Asia Pac J Clin Nutr 2: 35-41

38. Harris M (1990) Non-insulin-dependent diabetes mellitus in black and white Americans. Diabetes Metab Rev 6: 71-90

39. Harris MI (1989) Impaired glucose tolerance in the U.S. population. Diabetes Care 12: 464-474

40. Pan XR, Li GW, Hu YH et al. (1997) Effects of diet and exercise in preventing NIDDM in people with impaired glucose tolerance. The DaQing IGT and Diabetes study. Diabetes Care 20: 537-544

41. Davidson MB, Schriger DL, Peters AL (1995) An alternative approach to the diagnosis of diabetes with a review of the literature. Diabetes Care 18: 1065-1071

42. Stolk RP, Grobbe DE, Orchard TJ (1995) Why use the oral glucose tolerance test? Diabetes Care 18: 1045-1049 